\title{
Comparative Evaluation of Media Literacy Course: The Case of Turkey
}

\author{
Ayşe Asli Sezgin \\ Assistant Prof. / Osmaniye Korkut Ata University / aaslisezgin@gmail.com
}

Doi:10.5901/mjss.2015.v6n2s5p80

\begin{abstract}
In recent years, media literacy, as the result of unavoidable rapidly evolving technology, emerges as an issue that should be considered. Cause of the adult and children remain under the influence of early intensive of media messages, parents and educators are led to take measures against of the media messages. Today, it is not possible tos tay completely away from the media. Reading media messages and determine the useful content regarded as a correct behavior. Choosing the correct information in the media as the emergence of the information density, which is now in the position of issuing content viewer / listener / is an extremely important point for publishers. The aim of the this study is to reveal the comporative study of media literacy course and its implementation style which is starting in Turkey and yet close to take place in the curriculum of the past elemantry school between the courses in United States and schools in Europe. In this context, domestic and foreign sources written about media literacy were utilized. Concrete information on applications in Turkey in order to achieve the 2006-2007 academic year of the pilot school for the teaching of media literacy course Ankara Cankaya Ahmet Vefik Pasha Primary School was conducted in research. The questions designed to obtain information on the implementation of the course is directed on teacher; the results obtained are used as another source in the study. After the interviews, the mass media in our lives that encompasses all areas and reaching out to different sizes with technological innovation community life, which gained strength in a century that have a say in the media literacy traditional approach seen in the education system in Turkey is possible to say that its impact in the course. Especially when you compare it with samples in the world, the need when they need to take more important steps in Turkey's media literacy practices in both gold was drawn
\end{abstract}

Keywords: Media Literacy, Media Literacy Course, Media Literacy Course in Turkey

\section{Introduction}

In the conference held in Aspen Institute ${ }^{1}$ in 1992 , media literacy was defined as "skill of accessing messages in a vast variety of forms, analyzing, evaluating and conveying the same". In a different definition made in $1998^{2}$, media literacy was tried to be explained as "educational tool in school, a value for the conscious citizens, a variable for researchers, a cultural problem, common concern of the public" (RobbGrieco, 2007: 5)

Potter deliberated primarily on the notion of "literacy" and the definition of this notion while trying to explain media literacy. According to Potter, the notion of "literacy" for many people is comprehended as the skill to "read" by associating it with published-printed media. Some sources expanded this concept into "visual literacy" by including television and cinema into its composition. Some other sources made a classification of "computer literacy" in connection to technological developments (Potter, 2004: 33).

Reading, visual literacy or computer literacy are not synonyms for media literacy. Media literacy includes all these skills, traits and much more. We cannot understand printed media without reading; if we have difficulty understanding visual messages, we cannot benefit from visual media; if we do not know how to use a computer, we cannot follow the developments in this field. Conclusively, media literacy is a general notion that is much more than these characteristics (Potter, 2004: 34).

Media literacy comprises of points of view, which we open ourselves to effects directed by the media, and which allows us to interpret such messages. Points of view are formed with information. We need tools and raw material to form and construct information. These tools are our skills. Raw materials are information obtained from media and the environment. We should be aware of the messages and their interactions with each other (Potter, 2004: 34). Media literacy helps us sail in confidence on the sea of images and messages. Today, we no longer obtain information about the world via some words printed on pieces of paper. Effective images and sounds reach us through different media (Thoman

\footnotetext{
${ }^{2}$ Aspen Institute - Communications and Society Program: Aspen Report of National Leadership Conference on Media Literacy,
} December, 1992 
and Jolls, 2003: 21).

Media has its own visual-audial language, with its own rules, which are used to convey notions and opinions. Media literacy is the skill to accurately evaluate, analyze and reform media within its many different forms. Media literacy is the $21^{\text {st }}$ century approach to education (Thoman ve Jolls, 2003; 21). Media literacy is used to refer to the individual's learning of critical analysis process and forming its own messages (with published, audial, visual and multiple media) (Hobbs, 2004: 1).

Media literacy is defined as "an education program that makes individuals be informed about media texts, provides them to be more resistant to their potential harmful effects, and which invites media organizations to act more carefully by raising awareness in individuals" (RTUK, 2007;35) by Radio Television Supreme Council (RTUK), which is prominent with its initiatives about media literacy in Turkey.

Up to this section, we have tried to provide brief information about what media literacy is or is not. In the $21^{\text {st }}$ century, we can observe that media covers a major period of time when we analyze our daily lives. Media and messages conveyed by media has surrounded us to such an extent that this bombardment of messages continue even when we are not directly in contact with media. Especially in major cities, billboards on every step, advertisement monitors on mass transit vehicles continue to send messages without our awareness.

Media, without discriminating against age, has become the number one entertainment tool in our "spare time" as also included in Lefebvre's "daily live" notion. We, on the other hand, enable media to have an indispensible place in our lives by defining our consumption habits, means to access information, make use of our spare time and methods of communications via media itself.

In the $21^{\text {st }}$ century, in terms of understanding media better, which has such an important part in human lives, processing messages received from media with an aware and critical approach and most important of all, making the future generations become aware of this field, it has become mandatory to become media literates and teach media literacy in schools by teachers with sufficient knowledge about the field.

Teaching media literacy in schools as part of the curriculum will be an important step towards accurate understanding of media, accurate analysis of messages and making young generations media literates. However a delicate matter that should be emphasized at this point, is the necessity to avoid the "protective approach" that is dominant with regard to protecting children from harmful contents of media, or the approach that makes us surrender to media messages resulting from incomplete explanation of the media content. Adopting a unilateral approach, arguing against media or lacking the effort to accurately understand media shall cause faulty results to be obtained following a media literacy education. In brief, as stated by Erdogan ${ }^{3}$ (2009) "instead of becoming a viewer by following the 'view' prepared for us", it is necessary to correctly understand and convey media literacy; and come to conclusions by analyzing media in order to become critical viewers. "

\section{Methodology}

In this study, academic articles and books about media literacy and many local or foreign resources on the subject were examined with the literature review method. Especially the subject of "media literacy education" constitutes the common characteristics of these resources.

With the purpose to explain examples outside of Turkey, resources that are explanatory with regard to the curriculum system of such examples are considered. For examining the examples from Turkey, Media Literacy Teacher Handbook published by RTUK, and, Teacher Handbook published by MoE and RTUK were used, which include pictorial representations for explaining course applications. We have tried to accumulate information about applications in Turkey by using the online resources of RTUK, which is an important promoter with regard to Media Literacy course in Turkey, and web sites designed especially for this purpose.

Other than the literature review method, in the conclusion section of the study and with the aim to obtain some data on the media literacy course, an interview was held with a course teacher in a primary school where the course is selected by some students, after media literacy course was introduced to the curriculum as an elective course in Ankara. Questions that might effect the conclusion section of the study were directed to the teacher in this interview.

Furthermore, scope of the theoretical part of the subject was defined by researching the media literacy course application in some countries located in America and Europe. In the conclusion section, the boundaries of the study was defined with the primary school where media literacy course is an elective course, within the borders of Ankara province.

The main idea this study shows is that, in contrary to the world applications and along with the assumption that

${ }_{3}^{3}$ Media Literacy Symposuim, Journal of Communication, Winter, 1998. 
Turkey has fell behind in applying the course, media literacy course being introduced to only the primary schools demonstrates that the traditional educational approach of Turkey has reflected on the application of this course.

\section{Analysis and Discussion}

Initiatives on media literacy has started in the late 1920s and early 1930s in the USA. Upon concerns of parents, research on the effects of cinemas on children can constitute an example for these initiatives. Concerns of parents elevated with the publication of Fredric Wertham's "Seduction of the Innocent" 4 in 1954 (Kearney, 2006: 322). The first official media literacy program has entered the agenda with the proposal of Canada National Association of Educational Publishers (AEP) following the elevation of concerns toward the effects of media in 1959 (Kearney, 2006: 323).

Concerns about children's habit of watching television were revealed once again in USA in the early 1970s. These concerns once again elevated with the publication of Surgeon General's Scientific Advisory Committee's report on television and social behavior in 1972. According to this report, anti-social behaviors of children are in correlation with the violence scenes shown on television. In the following years, more reports were published, warning the public about paying more attention to mass communication tools. These reports enabled many research to be conducted on media literacy (Kearney, 2006: 323).

In 1980s, efforts about media education received support from educators, families and public officials in Canada, Austria and Britain, where little support was received in the USA. However, while media literacy course was in the curriculums of only twelve states in 1999, the number of states with the course reached forty-nine in two years. The reason for this, along with the support of the government and private organizations, can be summarized as support from public organizations comprised of teachers and media activists such as the Center for Media Literacy (Kearney, 2006: 323).

In an international conference entitled "Educating for the Media and the Digital Age" held in Vienna in 1999, many speakers from various countries conveyed their opinions on media literacy. Cecilia von Feilitzen, participating the conference from Sweden, approached the media literacy education from another angle. According to Feilitzen, there are differences between western and eastern countries with regard to media literacy education. While in countries such as Austria, Canada and European countries, media literacy education emphasized subjects such as criticism and independence; in countries such as India, Brazil and South Africa media literacy education emphasized subjects such as freedom, development of the society as a whole, and social justice (Feilitzen,1999: 4).

Media literacy, after being born and developed in the USA, has started to be accepted as an indispensible part of education in many other countries. Today, media literacy in France is operated by an agency entitled Center of Liaison Between Teaching and Information under the roof of the Ministry of Education. In Israel, it is emphasized that media literacy can be used as a tool for achieving social objectives. Another conspicuous aspect in Israel's application is that media literacy education is not tied to any central administration, and is applied according to the programs prepared by each separate school (Cho ve Heins, 2003: 36).

As a result of a study conducted in 1991 by the Ministry of Education of Australia on students enrolled in mid-level schools, it is observed that the students could not differentiate between real lives and fictional lives on television. The grounds for this observation was based on the inability for children to fully grasp life in those ages. Another reason suggested excess exposure to media messages. As result of the study, the importance of media literacy was emphasized for teaching critical thinking (Cho ve Heins, 2003: 37).

When we examine Russia, a different country than the ones in Europe and America, it is seen that the fundamental objective media literacy education is to prepare the young generation to the new and modern information realm, comprehend, understand and realize the psychological effects on humans of different information (Fedorov, 2003: 1).

Following the brief information on media literacy in the world, we shall provide information on how the course is applied in Turkey.

RTUK is the prominent body with regard to media literacy initiatives in Turkey. In the Teacher Handbook prepared by RTUK, gains of students following completion of media literacy education is defined as follows:

"The student, instead of remaining a passive receiver of media, it can resolve the language of media, and become an active individual within the notion of communication by reaching a state of awareness" (RTUK,2007: 4)

Media literacy course, started as a pilot application in primary schools in selected provinces, and was later introduced to the curriculum of all primary schools as an elective course. Furthermore, RTUK conducts additional studies in the online environment for encouraging media literacy education. Web sites prepared for this purpose encourage

${ }^{4}$ Henri Lefebvre, Modern Dünyada Gündelik Hayat, Metis Yayınları, 2. Baskı, İstanbul, 2007. 
media literacy. Additionally, painting and poem contests between primary school students are also remarkable in terms of their results.

It is possible to talk about other initiatives on media literacy in Turkey, such as the initiatives of the Ministry of Education. Teacher Handbook prepared by the MoE is another resource prepared for this course. In this study, with the purpose to have an opinion on the application of media literacy course in Turkey, an interview was conducted with a teacher of the course in a primary school located in Ankara. Results of this interview and comparison of media literacy education in Turkey and other countries shall be conveyed in the conclusion section below.

\section{Conclusion}

When we look at the education system of Turkey, we can state that it has a traditional structure. Educational activities that are conducted with traditional methods may cause difficulties in catching up with technological developments. Many aspects can be ignored in education activities directed at the class as a whole that do not take into consideration the personal and perception levels of students (Çetiner, Gencel and Erten, 1998).

Along with using the same methods in media literacy education, a "protective" approach shall delay the effective and goal-oriented results.

It is possible to make a comparison at some points with world applications:

1. Media literacy education has started many years ago in the USA and Europe. Media's long history of development in comparison to its Turkish examples may be one of the most important reasons for this.

2. The long passage of time has provided a change in approach to media literacy education. Although started out with a protective approach, today many countries have adopted the approach that defends the media literacy to lay out and examine media itself. Turkey has a long way to go in this sense.

3. Another important point in world examples is that almost all resources take into hand the "media education" before talking about media literacy course. Importance attributed to media education demonstrates the requirement for emphasis on providing the media literacy course by teachers, who possess the required knowledge and foundations for teaching this course. Today in Turkey, faculty of communication graduates who possess the required knowledge on media cannot become teachers of this course.

4. Another important point regarding media literacy course around the world is the sensitivity of civil society on this matter. Associations founded by educators, families, academicians and public officials aim to attract attention to media literacy. Similar organizations that will be formed in Turkey surely will attract attention on media literacy.

5. Although criticism and informed approach and media literacy itself in brief is explained appropriately in resources prepared by RTUK and MoE, both of which intends to point to the importance of media literacy education in Turkey, different attitudes stand out in application of such teachings. RTUK's Intelligent Signs application is a good example for this.

At this point, we can talk about the interview and the level media literacy course has arrived in Turkey:

The interview was held at Ankara Çankaya Ahmet Vefik Paşa Primary School, which was selected as the pilot school for implementing the media literacy course in the academic year of 2006-2007. Course teacher is the teacher of social studies. The teacher, who stated that the course was assigned by the school administration, started to apply the course on 125 students after attending a training program. The teacher, who uses the Teacher Hand Book prepared by $\mathrm{MoE}$, stated that the content of the book is insufficient and information presented by the book are merely summaries of the topic. It was also stated that the school materials are deficient and only printed mass communication tools could be used. An important point was made about the difference of male and female students in selecting the content they wanted to read in the newspaper reading application; accordingly male students preferred reading sports news, while female students preferred the tabloid content.

The teacher stated that no foreign resources are used during the course, and especially emphasized that warning against the negative effects of media was conveyed to students. Finally, when we asked whether they have any extracurricular suggestions, we received the reply that there should be resources in place for students as well, as special materials for students could make the course more effective.

As a result, we can state that there are many obstacles in teaching media literacy in Turkey that are yet to be overcome, and the traditional and protective education approach prevents the course to achieve its actual goal. In order for the obstacles to be overcome, the course should be taught by faculty of communication graduates who have the sufficient knowledge on the subject; transformed from elective to mandatory by forming civil society organizations for this purpose; and scoring system should be introduced to the course to enhance its importance both for teachers, administration and students alike. 


\section{References}

Fedorov, A. 2003. "Media education and media literacy: experts' opinions", Unesco.

Fellıtzen, C. V. 1999. "Educating for the media and the digital age", International Conference, Vienna, 18-19 April.

Gencel, Ç. Çetiner, H. Erten, M. 1998. "İnternete dayalı uzaktan eğitim ve çoklu ortam uygulamaları", ODTÜ Enformatik Enst. Bilişim Sistemleri USA, Received from (http: //erten. etu. edu. tr/genel-egit. pdf)

Heıns, M. , Cho, C. 2003. "Media literacy an alternative to cencorship", Free Expression Policy Project.

Hobbs, R. 2004. "Medya okuryazarlığı hareketinde yedi büyük tartışma", çev. Melike Türkan Bağlı, A. Ü. Eğitim Bilimleri Fakültesi Dergisi, cilt: 37, sayı: 1. http: /len. wikipeida. org/wiki/Seduction_of_the Innocent

İlköğretim Medya Okuryazarlı̆̆ı Dersi Öğretmen El Kitabı,2007. Ankara: RT̈̈̈K.

Jolls, T. , Thoman, E. 2003. "Literacy for the 21st century, an overview and orientation guide to media literacy education", Center for Media Literacy, Received from: www. medialit,org/medialitkit

Kearney, M. C. 2006. Girls Make Media, CRC Press.

Lefebvre, H. 2007. Modern dünyada gündelik hayat, Metis Yayınları: İstanbul.

Potter, W. J. 2004. Media literacy: a cognitive approach, SAGE.

Robbgrıeco, M. 2007. "Media literacy as an Independent and Interactıve variable in the knowledge gap hypothesis", Media Education Lab, Temple University, School of Communications and Theater, Media Education Lab, Spring, Received from: www. mediaeducationlab. com/pdf/202_working\%20papers. pdf 